\title{
An atlas to support the progressive control of tsetse-transmitted animal trypanosomosis in Burkina Faso
}

Lassane Percoma ${ }^{1,2^{*}}$, Jean Baptiste Rayaissé ${ }^{3 \wedge}$, Geoffrey Gimonneau ${ }^{3,4,5}$, Zakaria Bengaly ${ }^{3}$, Sié Hermann Pooda ${ }^{6,1}$, Soumaïla Pagabeleguem ${ }^{6,1}$, Rasmané Ganaba7, Adama Sow ${ }^{8}$, Rafael Argilés 9 , Jérémy Bouyer ${ }^{4,9,10}$, Moussa Ouedraogo ', Weining Zhao ${ }^{11}$, Massimo Paone ${ }^{11}$, Issa Sidibé1,3, Ouedraogo/ Sanon Gisele ${ }^{1}$ and Giuliano Cecchi ${ }^{11}$ (i)

\begin{abstract}
Background: African animal trypanosomosis (AAT), transmitted by tsetse flies, is arguably the main disease constraint to integrated crop-livestock agriculture in sub-Saharan Africa, and African heads of state and governments adopted a resolution to rid the continent of this scourge. In order to sustainably reduce or eliminate the burden of AAT, a progressive and evidence-based approach is needed, which must hinge on harmonized, spatially explicit information on the occurrence of AAT and its vectors.

Methods: A digital repository was assembled, containing tsetse and AAT data collected in Burkina Faso between 1990 and 2019. Data were collected either in the framework of control activities or for research purposes. Data were systematically verified, harmonized, georeferenced and integrated into a database (PostgreSQL). Entomological data on tsetse were mapped at the level of individual monitoring traps. When this was not possible, mapping was done at the level of site or location. Epidemiological data on AAT were mapped at the level of location or village.
\end{abstract}

Results: Entomological data showed the presence of four tsetse species in Burkina Faso. Glossina tachinoides, present from the eastern to the western part of the country, was the most widespread and abundant species (56.35\% of the catches). Glossina palpalis gambiensis was the second most abundant species (35.56\%), and it was mainly found in the west. Glossina morsitans submorsitans was found at lower densities (6.51\%), with a patchy distribution in the southern parts of the country. A single cluster of G. medicorum was detected (less than $0.25 \%$ ), located in the south-west. Unidentified tsetse flies accounted for 1.33\%. For the AAT component, data for 54,948 animal blood samples were assembled from 218 geographic locations. The samples were tested with a variety of diagnostic methods. AAT was found in all surveyed departments, including the tsetse-free areas in the north. Trypanosoma vivax and T. congolense infections were the dominant ones, with a prevalence of $5.19 \pm 18.97 \%$ and $6.11 \pm 21.56 \%$, respectively. Trypanosoma brucei infections were detected at a much lower rate $(0.00 \pm 0.10 \%)$.

Conclusions: The atlas provides a synoptic view of the available information on tsetse and AAT distribution in Burkina Faso. Data are very scanty for most of the tsetse-free areas in the northern part of the country. Despite this limitation, this study generated a robust tool for targeting future surveillance and control activities. The development

*Correspondence: percomalas@yahoo.fr

1 Insectarium de Bobo-Dioulasso-Campagne Panafricaine d'Eradication

de la Tsé-tsé et de la Trypanosomose, Bobo-Dioulasso, Burkina Faso

Full list of author information is available at the end of the article permits use, sharing, adaptation, distribution and reproduction in any medium or format, as long as you give appropriate credit to the original author(s) and the source, provide a link to the Creative Commons licence, and indicate if changes were made. The images or other third party material in this article are included in the article's Creative Commons licence, unless indicated otherwise in a credit line to the material. If material is not included in the article's Creative Commons licence and your intended use is not permitted by statutory regulation or exceeds the permitted use, you will need to obtain permission directly from the copyright holder. To view a copy of this licence, visit http://creativecommons.org/licenses/by/4.0/. The Creative Commons Public Domain Dedication waiver (http://creativeco mmons.org/publicdomain/zero/1.0/) applies to the data made available in this article, unless otherwise stated in a credit line to the data. 


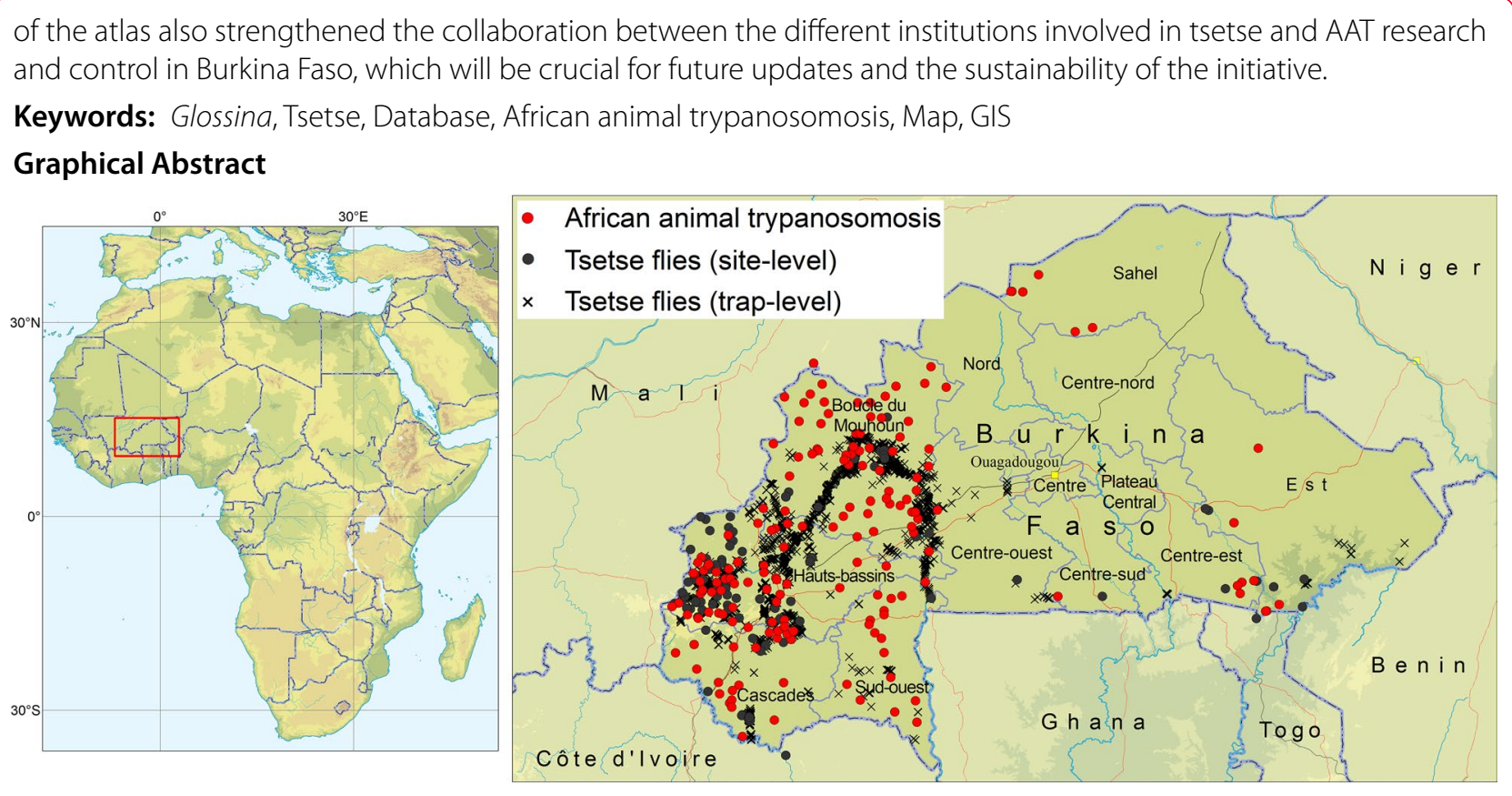

\section{Background}

Tsetse flies are the biological vectors of African trypanosomosis, a parasitic disease that affects both humans (sleeping sickness) [1] and animals (nagana) [2]. These diseases have historically hindered the development of the African continent [3], and they persist today as a major constraint to mixed crop-livestock agriculture, food security and human health [4]. The annual economic losses attributed to African animal trypanosomosis (AAT) are measured in billions of dollars [5, 6], while more than 50 million people are still considered at risk of contracting human African trypanosomosis (HAT) $[7,8]$.

In Burkina Faso, the expenditure on the trypanocides used for the preventive and curative treatment of livestock, mainly cattle, has been estimated at 3.9 million US\$ per annum [9]. A total of 2.6 million doses of trypanocidal drugs are used every year to control the disease $[9,10]$, and 9 out of the 13 regions of the country are affected by tsetse flies. More than $60 \%$ of the country's cattle population is raised in zones with high trypanosomosis risk $[11,12]$. In particular, many zones where grazing potential for cattle is high and human activities are limited, also provide suitable habitats for tsetse flies [12].

In 2000, the Government of Burkina Faso, along with other African countries in the Pan-African Tsetse and Trypanosomosis Eradication Campaign (PATTEC), embarked on an initiative led by the African Union [13]. At the country level, a project in the PATTEC framework was implemented between 2006 and 2013 [14].
The project generated a vast amount of data, while other activities and projects implemented by other stakeholders also collected field data on the occurrence of AAT and its vectors in Burkina Faso. Unfortunately, the data generated by these activities and institutions have not been harmonized and centralized.

National atlases of tsetse and AAT are considered indispensable tools for efficient disease management in the context of the progressive control pathway (PCP) for AAT [15]. In 2013, the Food and Agriculture Organization of the United Nations (FAO) launched a multinational project to support six AAT-affected countries (i.e. Burkina Faso, Mali, Ghana, Kenya, Ethiopia and Uganda), and one of its goals was to promote the development of the national atlases. The Insectary of Bobo Dioulasso-Tsetse and Trypanosomosis Eradication Campaign (Insectarium de Bobo Dioulasso-Campagne d'Eradication de la mouche Tsé-tsé et de la Trypanosomose-IBDCETT, formerly PATTEC Burkina Faso), implemented the FAO project in Burkina Faso as the specialized national structure in charge of tsetse and AAT control. IBD-CETT also took the lead in the development of the atlas.

\section{Methods}

The methodology to develop the atlas of tsetse and AAT in Burkina Faso is broadly based on the FAO continental atlas [16-18], and a similar approach has already been used at the national level in Sudan [19], Mali [20], Kenya 
[21] and Zimbabwe [22]. The main difference between the continental and the national atlases is that the former is solely based on publicly available data from scientific journals, while the latter include all published or unpublished data collected in a given country.

The atlas in Burkina Faso covers a period of 30 years (1990-2019). Data were provided by all the institutions involved in tsetse and trypanosomosis research and control at the national level. In addition to IBD-CETT, these are the School of tsetse control (Ecole de Lutte Anti-Tsétsé-ELAT), the International Research and Development Centre on Livestock Farming in the Subhumid Zone (Centre International de Recherche-Développement sur l'Elevage en zone Subhumide-CIRDES), the French Agricultural Research Centre for International Development (Centre de coopération Internationale en Recherche Agronomique pour le Développement-CIRAD), the French Research Institute for Development (Institut de Recherche pour le Développement-IRD), the International Atomic Energy Agency (IAEA) and FAO.

\section{Input data}

Input data were collected either in the framework of tsetse and trypanosomosis control operations or in the context of research activities. Control operations were mostly carried out by PATTEC Burkina Faso by using impregnated targets and traps and animal treatment. Data included both baseline cross-sectional surveys (i.e. pre-intervention) and longitudinal surveys (i.e. during or post-intervention), and provided a large amount of unpublished information. The raw data from research activities were obtained from the authors of published articles, using as a basis the systematic review of the literature carried out by FAO for the continental atlas. The full list of publications that contributed to the national atlas in Burkina Faso is provided in Additional file 1: Text S1. When the raw data underpinning publications could not be retrieved, information on AAT and tsetse occurrence was extracted directly from the papers, as done for the continental atlas.

\section{Tsetse data}

In Burkina Faso, entomological surveys are mainly carried out with biconical traps [23], which may or may not be boosted with odour attractants [24]. However, other traps such as monoconical Vavoua trap [25] [26, 27], N'Zi traps, adhesive targets and electric targets were also occasionally used in experimental settings [28]. The trapping duration was usually 3 days for the surveys carried out in the framework of control activities, and 1 to 3 days for research activities. All traps were geo-referenced with GPS.
Entomological data were recorded at the level of individual traps. Data were initially captured in hard-copy recording sheets, which were subsequently converted into digital format (e.g. Microsoft Excel or Access). Field recording sheets include information such as the name of the surveyed location, its coordinates and administrative units (which in Burkina Faso are called regions, provinces and departments), the date of the survey, the time of trap deployment and removal (and the corresponding duration of trapping), and the number, species and sex of trapped tsetse flies. Complementary information (type of trap, use of odour attractants, etc.) is normally available in mission or project reports. For research activities linked to scientific publications, raw datasets at the trap level were normally obtained. When these were not available, information was mapped at the site level.

\section{African animal trypanosomosis data}

As for tsetse, AAT data were mainly collected in the framework of control activities, thus including both baseline and monitoring/longitudinal investigations. Supplementary data were generated in the context of research.

AAT surveys in Burkina Faso target the main susceptible animal species such as cattle, sheep, goats and donkeys, but data on horses and camels are also occasionally collected. In most surveys, the sampling locations and the animals are selected randomly. However, a non-random sampling was sometimes performed, for example in studies of trypanocidal drug resistance $[29,30]$, or for the isolation of trypanosomes. Cross-sectional surveys provided the majority of datasets included in the atlas, but longitudinal investigations were also included [14].

Field data recording sheets for AAT include the data source and the institution in charge, the name, geographical coordinates and administrative units pertaining to the survey village or site, the date of the survey and the sample size (i.e. the number of animals tested). The sheets also include parasitological results such as the number of AAT-positive animals by trypanosome species, the haematocrit (packed cell volume-PCV) and the possible use of trypanocidal drugs (including the type of drug).

AAT data are recorded at the level of individual animal in the parasitological recording sheets, and information at the animal level was retained in the atlas. When the animal level data were not available, aggregated information at the herd/site level was recorded.

\section{Structure of the atlas}

The atlas is composed of a structured data repository and two databases (tsetse distribution and AAT distribution). Data on tsetse infections are not yet included. 
Open-source PostgreSQL is used as the main database management system, together with its spatial extension PostGIS. Microsoft Access is used to facilitate a broader data utilization.

\section{Data repository}

The data repository includes digital copies of all the input files used to build the atlas, i.e. spreadsheets, databases, reports, thesis and scientific articles. At a first level, the repository is organized by type of data (i.e. tsetse or AAT), at a second level by geographical area (i.e. province), and last by individual data source or publication. File names for scientific publications are standardized as author name and year of publication (i.e. Surname_ YEAR.pdf), and for unpublished works as title of activity and year.

\section{Tsetse database}

Entomological data recorded in the tsetse database are organized in six tables: 1) data sources; 2) geographical data; 3) entomological surveys (trap level); 4) tsetse catches (trap level); 5) entomological surveys (site level); and 6) tsetse catches (site level). As in all relational databases, records in each table are given a unique identifier, the 'primary key', which allows them to be linked to records in other tables through 'foreign keys'.

The table on 'data sources' summarizes information on the input files stored in the repository. In particular, it records the following information: institution, author's name, title, year of production/publication, presence of information on tsetse or AAT, availability of raw data and whether the source is published or not. The 'geographical data' table includes the location or village name, its geographical coordinates and the corresponding administrative units. The table on 'entomological surveys' (trap level) includes the code of the trap (as per survey recording sheet), the type of trap, the attractant used (if any), the geographical coordinates of the trapping site (latitude and longitude in decimal degrees on WGS84 datum), the trapping period and its duration. Information on the possible presence of tsetse control activities in the surveyed area is also recorded. The table on 'tsetse catches' (trap level) summarizes the results of the trapping and includes the tsetse species, sex and the number of flies caught.

The tables on 'entomological surveys' and 'tsetse catches' (site level) record data that were directly extracted from scientific publications when raw data at the trap level could not be obtained. These site-level tables of the national atlas for Burkina Faso have a similar structure to those of the continental atlas [17].
The detailed structure of the tsetse database, including the relationships between the tables, is provided in Additional file 2: Text S2.

\section{African animal trypanosomosis database}

The database for AAT contains seven tables: (1) data sources; (2) geographical data; (3) animal species; (4) diagnostic method; (5) AAT data (animal level); (6) AAT data (herd level); and (7) chemotherapy.

The tables 'data sources' and 'geographical data' are similar to those of the tsetse database. The table 'animal species' records the species and breed of tested animals, and the table 'diagnostic method' provides details on the diagnostic test used to detect AAT. The table 'AAT data' (animal level) includes the code of the animal (as per survey recording sheet), its age, sex, haematocrit/ $\mathrm{PCV}$, health status, treatment with trypanocidal drugs, date of last treatment, husbandry system, date of survey, presence or absence of trypanosomes, species of trypanosomes (including subspecies/groups), type of animal sampling (random or purposeful), type of survey (longitudinal or cross-sectional) and possible presence of vector control operations during the survey. The table 'AAT data' (herd level) is used to capture data extracted from scientific publications when the raw data at the animal level could not be obtained; as such, it follows the structure of the continental atlas [16]. The last table (chemotherapy) provides details on the possible treatment of animals with anti-trypanosomal drugs before the survey. It includes the date and cause of treatment, the drug used, the doses and the person who administered the treatment.

The detailed structure of the AAT database, including the relationships between the tables, is provided in Additional file 3: Text S3.

\section{Development of the atlas}

The first step in the development of the atlas was to collect input data from all partner institutions. Workshops and meetings were organized to facilitate the process. When input data could only be retrieved as hard copy, Microsoft Excel was used to enter data in digital format.

Merging data from a variety of sources into the atlas databases required a systematic process of verification and harmonization. Geographical coordinates were standardized as latitude and longitude (decimal degrees on WGS84 datum). When Universal Transverse Mercator (UTM) coordinates were reported in the input files, coordinate transformation was performed. Extensive harmonization was also needed for data on animal 


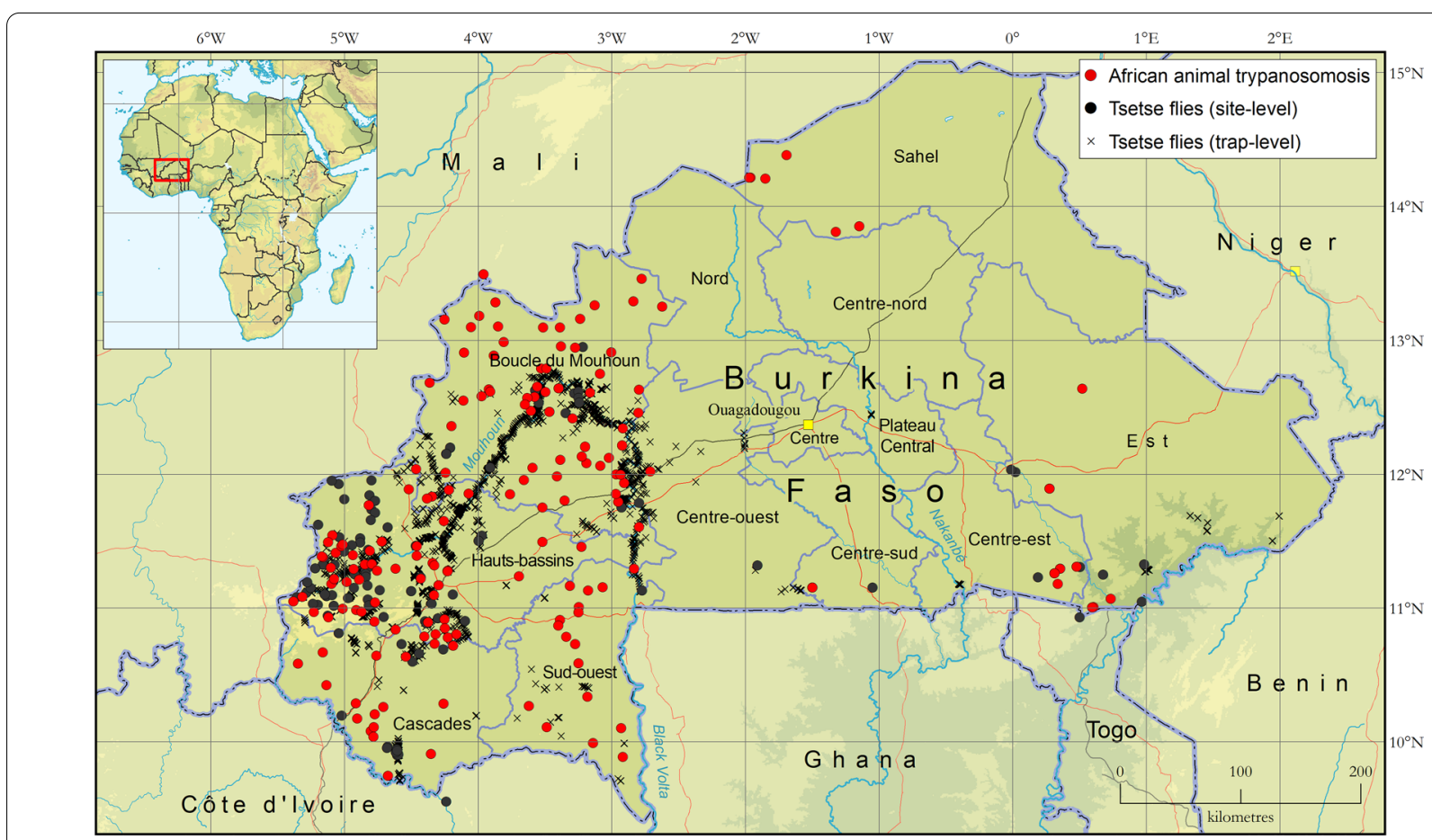

Fig. 1 The occurrence of African animal trypanosomosis and tsetse flies (genus: Glossina) in Burkina Faso. Data collection period: 1990-2019

breeds, husbandry systems, names of geographical locations and the related administrative units. For tsetse data, the names of locations were often missing. For AAT data, a high proportion of epidemiological records lacked geographic coordinates; in these cases, the names of the survey sites were used to extract geographic coordinates from other sources (i.e. Geographical Institute of Burkina Faso, Google Earth and Google Maps). Also, input data sheets often lacked information on whether interventions against tsetse were taking place in the study area at the time of the survey, or whether trypanocidal drugs were being used. In these cases, reports and publications were often useful to fill the gaps. When raw data could not be retrieved, information was extracted directly from the papers; for example, the maps included in the publication were imported in the GIS and georeferenced to estimate the geographical coordinates of the study sites.

\section{Results}

A total of 2261 data recording sheets were included in the atlas repository ( 723 for the tsetse component and 1538 for the AAT component). The review of the published and grey literature also enabled us to identify 105 eligible documents, including scientific papers, $\mathrm{PhD}$ and MSc theses, and activity reports.

The results of the atlas are summarized in Fig. 1, which shows the locations where tsetse flies and AAT were detected in Burkina Faso during the period 1990-2019.
Locations where surveys were conducted but tsetse and AAT were not detected are not shown in Fig. 1, although they are included in the database of the atlas.

\section{Tsetse fly distribution}

Entomological data on tsetse fly distribution were assembled for a total of 19,960 tsetse trapping events in 10,022 distinct trapping locations, including 9768 locations at the trap level and 254 locations at the site level. 'Site' locations normally refer to groups of traps, and they were used to map data from publications when the underlying trap-level data could not be obtained. The overall trapping intensity was 48,345 trap days.

The bulk of the entomological data included in the atlas are from the western and south-western part of the country. In particular, intensive baseline and monitoring surveys were conducted between 2007 and 2013 in the region at the Loop of the Mouhoun River (Boucle du Mouhoun), in the framework of an attempted large-scale elimination campaign [14, 24]. Entomological surveys are limited in most of the other regions, and especially in the northeastern parts of the country that are believed to be free of tsetse.

The device most commonly used to trap flies was the biconical trap [23], which was used in more than $95 \%$ of the surveys and often boosted with an odour attractant (77.31\% of traps). Other trapping devices used were sticky targets [27], electric targets [28] and N'zi traps [31]. 


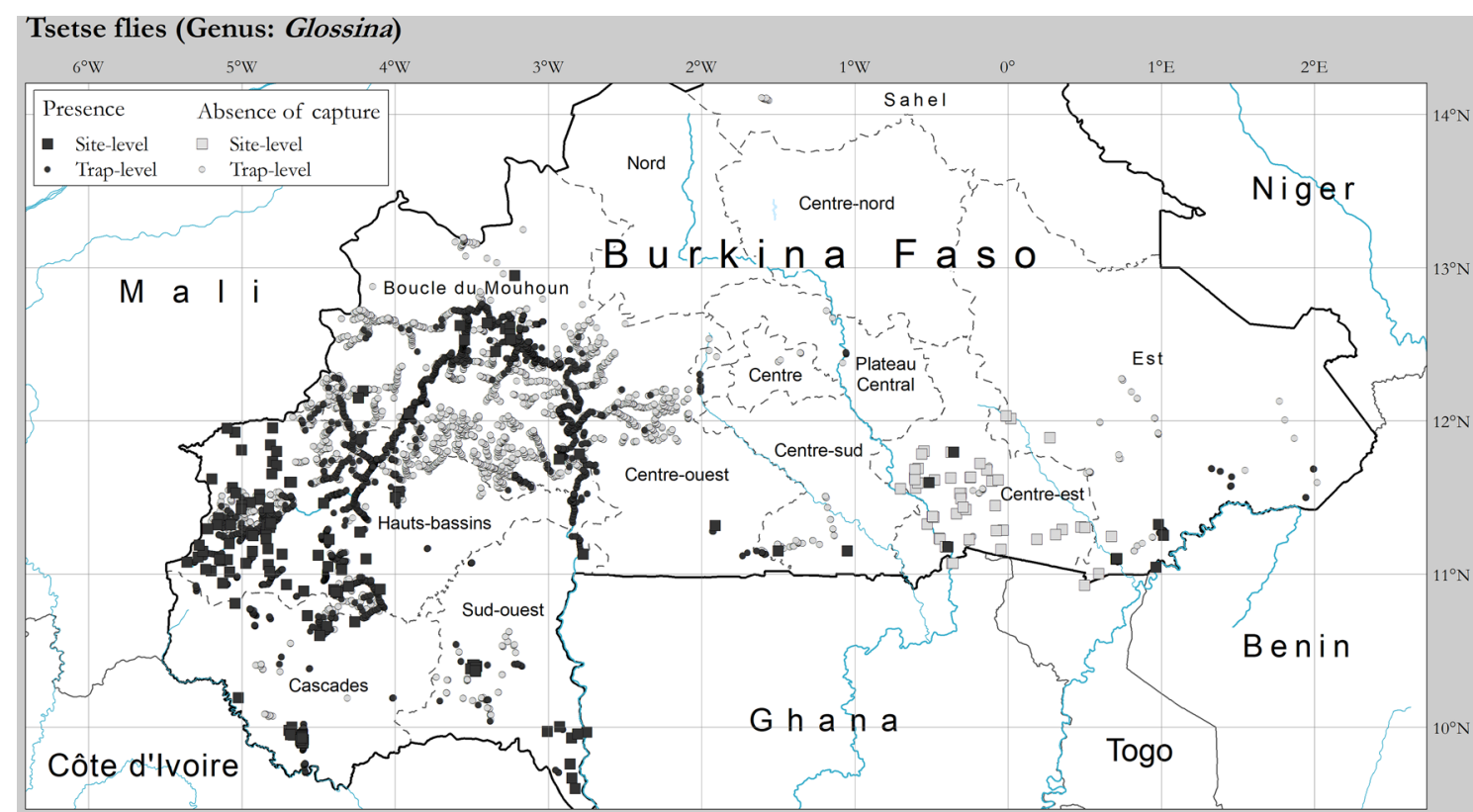

Palpalis group (subgenus: Nemorhina)
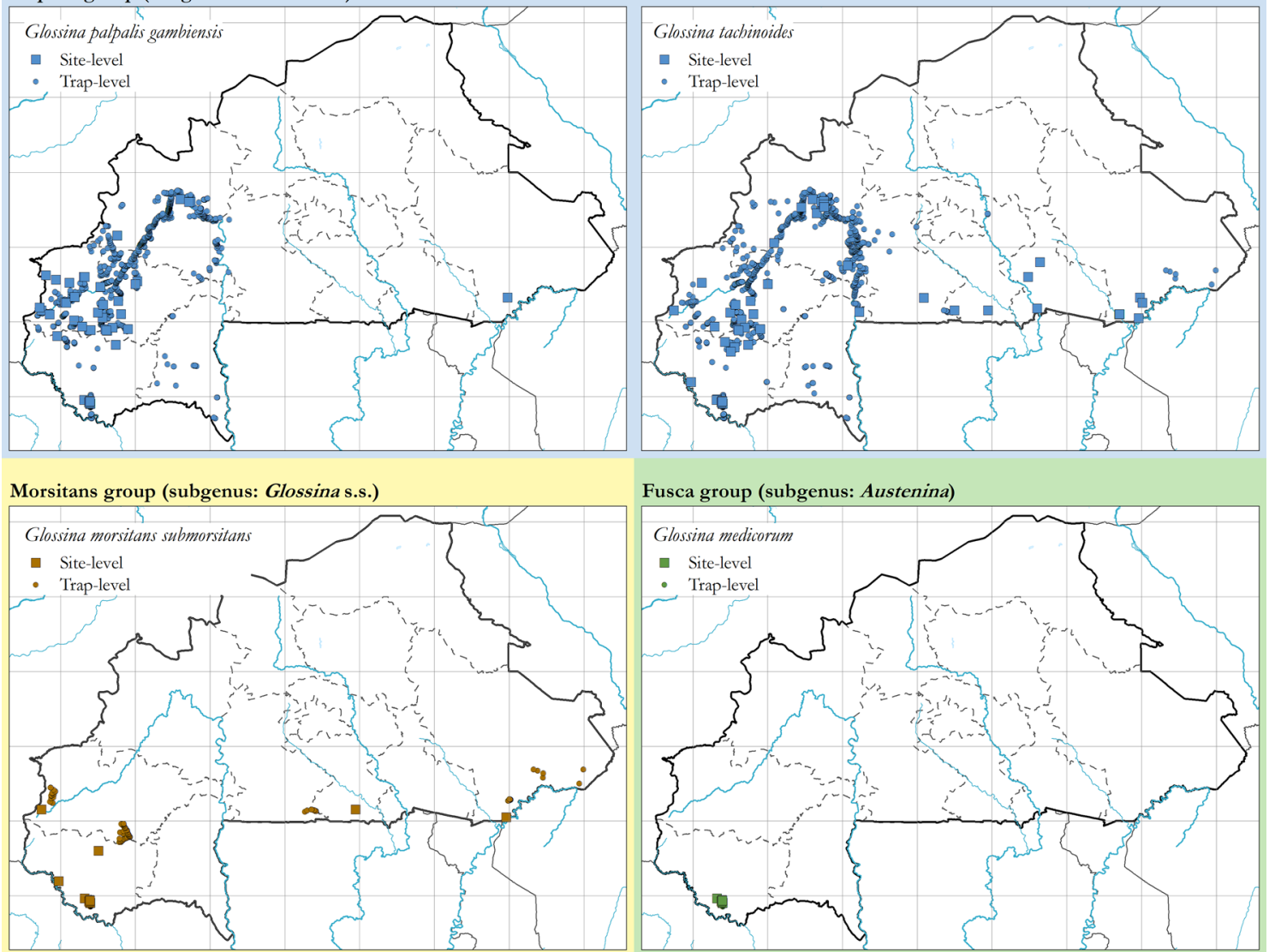

Fig. 2 Presence and absence of capture of G. palpalis gambiensis, G. tachinoides and G. morsitans submorsitans and G. medicorum in Burkina Faso. Data collection period: 1990-2019 
A total of 126,849 tsetse flies were caught in all the surveys included in the atlas, representing all three taxonomical groups (subgenera) historically present in Burkina Faso. The vast majority of catches belong to the palpalis group (91.91\%), in particular Glossina palpalis gambiensis (35.56\%) and G. tachinoides (56.35\%). Flies of the morsitans group were represented by G. morsitans submorsitans, which accounted for $6.51 \%$ of the overall catches. Glossina medicorum of the fusca group accounted for $0.25 \%$ of the catches. Approximately $1.33 \%$ of flies collected were not identified to the species level.

In terms of geographic distribution, G. palpalis gambiensis and G. tachinoides were found to be widespread in the western part of the country (Fig. 2), in particular along the major river systems (Mouhoun, Bourgouriba and Comoe) and their main tributaries. In the eastern part of the country, G. palpalis gambiensis was detected in only one location of Arly National Park, while G.

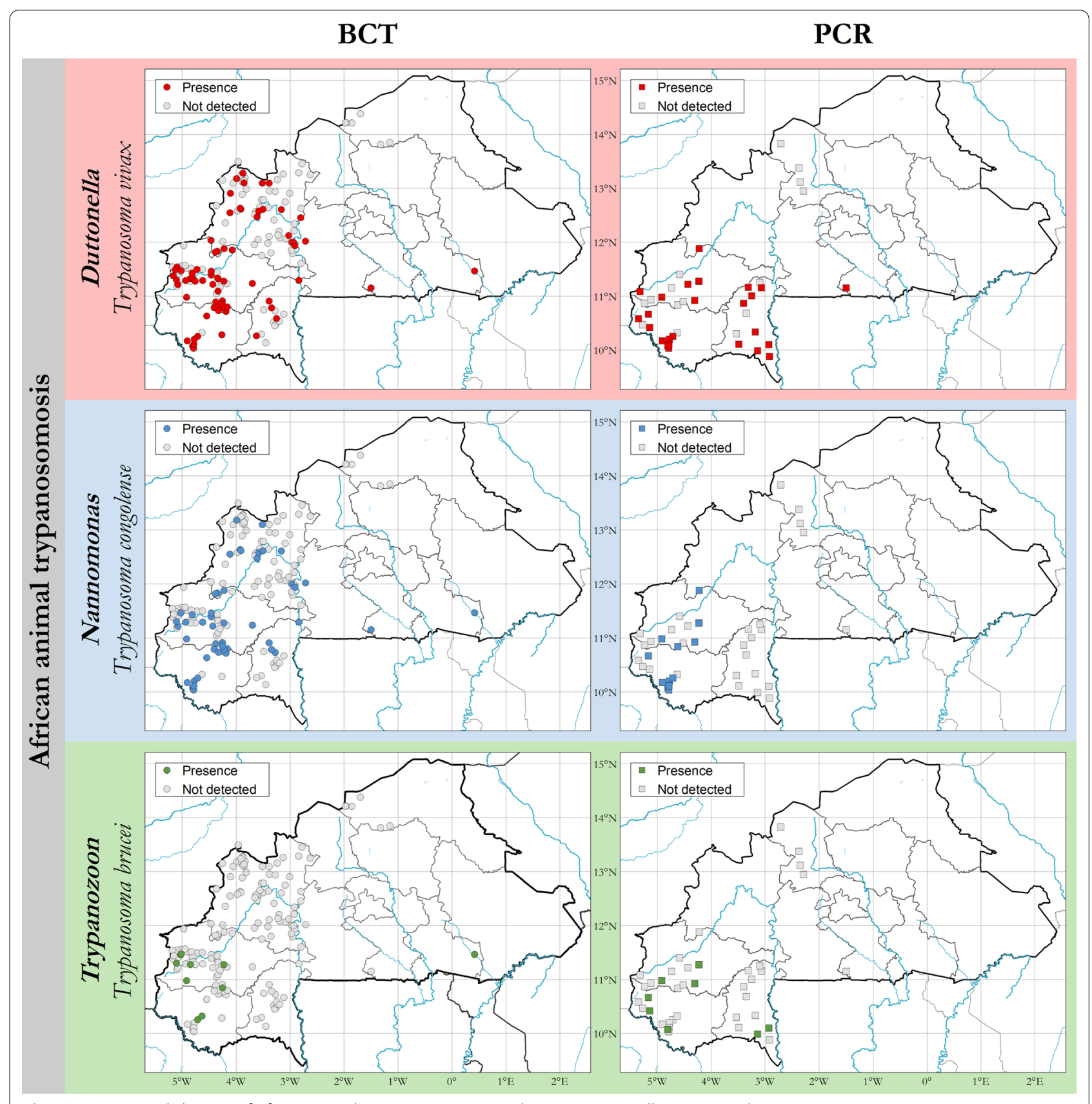

Fig. 3 Presence and absence of African animal trypanosomosis in Burkina Faso. Data collection period: 1990-2019 
tachinoides was found in several locations, and especially in protected areas (e.g. Nazinga Game Ranch and Arly National Park) [32]. The distribution of flies of the morsitans and fusca groups was more circumscribed. Glossina morsitans submorsitans was present in a few locations in the southern parts of the country, and strictly limited to protected areas, whereas G. medicorum was only found in one protected area in the south-east (Diefoula Forest and Logoniegue Forest).

\section{African animal trypanosomosis distribution}

In the AAT component of the atlas, the results of AAT diagnosis for 54,948 animal's blood samples were included, originating from 218 distinct geographic locations. Cattle account for $90.37 \%$ of animals tested $(n=49,654)$, followed by sheep $(5.20 \% ; n=2859)$, goats $(2.29 \% ; n=1258)$ and donkeys $(2.10 \% ; n=1154)$. Very limited data were found on horses $(n=21)$ and camels $(n=2)$.

AAT was confirmed to be present in all the tsetseinfested areas, in particular in the southern and southwestern parts of the country. Hotspots of transmission appear to be located in the areas bordering Côte d'Ivoire and Mali, and in the Mouhoun River basin. To a lesser extent, transmission occurs in the eastern part of the country, especially in the areas bordering Togo and Benin near the Arli National Park (Fig. 3). Serological cases of the disease were also found in some of the tsetse-free areas in the northern part of the country [33], at a distance of over $200 \mathrm{~km}$ from the tsetse-infested belt [32]. However, very limited surveillance is carried out in these tsetse-free areas, and the true extent of the AAT problem in these regions cannot be ascertained with the available data.

The buffy coat technique (BCT) [34] was the diagnostic method most frequently used for the detection of trypanosomal infections $(62.59 \%$ of all samples, $n=34,390)$, followed by serological techniques, more specifically enzyme-linked immunosorbent assay (ELISA) (28.63\% of all samples, $n=15,733)[12,35]$, and molecular techniques, in particular polymerase chain reaction (PCR) $(8.78 \%, n=4825)$ [36] (Fig. 4). Trypanosomosis prevalence was variable among hosts and diagnostic techniques. For cattle, an overall prevalence of $6.06 \%$ for BCT $(1881 / 31,048), 45.83 \%$ for ELISA $(6316 / 13,781)$ and $30.86 \%$ for PCR $(1489 / 4825)$ was found (Table 1$)$.

Three species of trypanosomes pathogens for livestock, Trypanosoma vivax, T. congolense and T. brucei, were found. Parasitological techniques showed an overall prevalence of $5.58 \%$ (1921 infections/34,390) and $30.68 \%$ (1489 infections/4825) for molecular techniques, while serological technique showed an overall prevalence of $41.90 \%$ (6592 infections/15,733). Trypanosoma vivax and $T$. congolense were the most common species responsible for AAT. The parasitological prevalence by BCT for $T$. vivax was $5.19 \pm 18.97 \%$ (673 infections) and $6.11 \pm 21.56 \%$ (721 infections) for T. congolense. Trypanosoma brucei was detected at smaller rates $(0.00 \pm 0.10$; 7 infections). With PCR, the prevalence was $14.78 \pm 23.11 \%$ and $9.49 \pm 19.20 \%$ for T. vivax and T. congolense, respectively. The prevalence of $T$. brucei was $0.11 \pm 0.84 \%$ (Table 1).

\section{Database completeness}

A high level of completeness was achieved in the atlas database. Regarding the tsetse component, the required information items could be found for the vast majority of the entomological records, in particular trap coordinates (83.57\%), administrative units $(100 \%)$ [i.e. region, province, department], location names (89.69\%), date of trapping (99.52\%), duration of trapping (97.25\%), type of trap (99.25\%), tsetse species (98.65\%), tsetse apparent densities (97.25\%) and control interventions against tsetse (76.34\%). The majority of trap coordinates were in UTM (75.72\%), so they had to be converted into geographical coordinates (Decimal Degrees). Regarding the AAT component, a similarly high level of completeness was achieved for geographical coordinates (87.12\%), administrative units (90.72), location names (90.49\%), survey period $(97.40 \%)$, sample size $(100 \%)$, number and species of infected animals (84.89\%), sampling strategy (i.e. random or purposeful) (95.93\%), chemotherapy (67.77\%) and possible interventions against tsetse (84.37\%).

\section{Discussion}

Our review of the published and unpublished data provides a synoptic picture of the distribution of tsetse fly and AAT in Burkina Faso for the period 1990-2019. The atlas updates the latest national tsetse distribution map produced in 1977 [37], whose northern limit had been updated in 2010 [32]. Distribution maps of the four tsetse species present in Burkina Faso are also presented. As far as AAT is concerned, the distribution maps presented in this paper, based on the testing of over 50,000 animals, are the first of their kind in Burkina Faso.

However, as observed in similar national mapping exercises [19-22], a number of gaps not attributable to the data compilation and processing still affect our knowledge of the distribution of tsetse fly and AAT in Burkina Faso. The gaps are related to the inherent limitations of the existing datasets, and in particular to the geographical coverage, range of animal species tested and diagnostic methods.

With regard to the geographical coverage, the main gap in the atlas is the severe lack of information from the north, north-east, north-west, centre and extreme east 

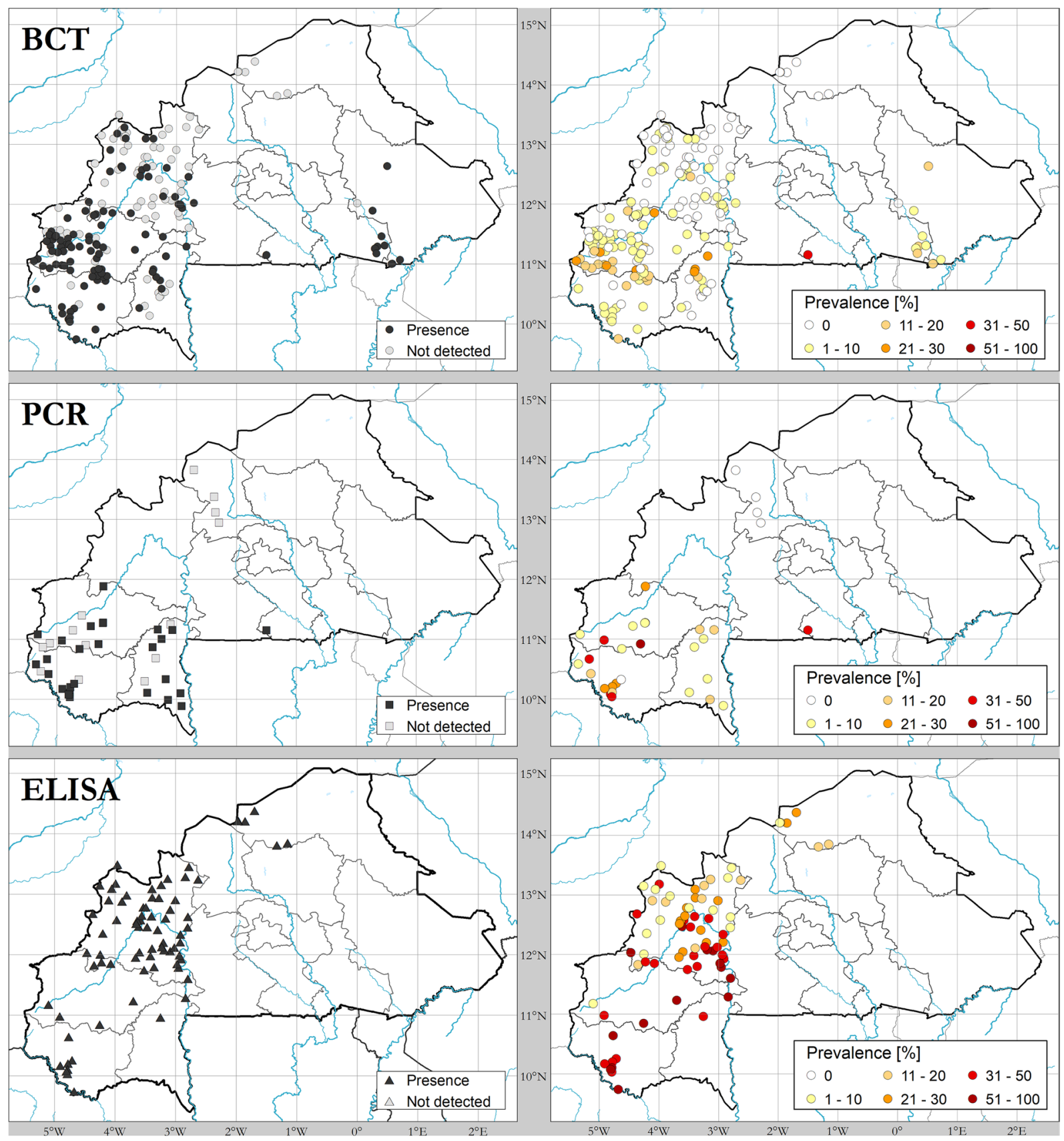

Fig. 4 Presence and absence and prevalence of African animal trypanosomosis in Burkina Faso with different diagnostic methods. Data collection period: 1990-2019

of the country. This situation is explained by the fact that institutions involved in tsetse and AAT research and control in Burkina Faso focus their investigations and efforts on the regions of highest tsetse infestation $[14,38])$. On the other hand, the northern and eastern regions are plagued by insecurity, which severely limits field data collection activities in these areas. As already observed in
Mali [20], this lack of information for a large part of the national territory hides the true extent of the AAT problem in the country.

As regards the animal species tested for AAT, more than $90 \%$ of the atlas data are on cattle. However, in Burkina Faso small ruminants (i.e. sheep and goats) far exceed cattle in terms of population numbers. 
Table 1 Prevalence of AAT (Trypanosoma sp.) in different host species and by different diagnostic techniques in Burkina Faso (period: 1990 and 2019)

\begin{tabular}{|c|c|c|c|c|c|c|c|c|c|c|c|c|c|c|}
\hline \multirow[t]{2}{*}{ Diagnostic method } & \multirow[t]{2}{*}{ Animal species } & \multirow{2}{*}{$\begin{array}{l}\text { Animals tested } \\
{[n]}\end{array}$} & \multicolumn{4}{|c|}{ Number of infections $[n]$} & \multicolumn{4}{|c|}{ Mean prevalence [\%] } & \multicolumn{4}{|c|}{ Standard deviation [\%] } \\
\hline & & & Tc & TV & $T b$ & $T$ & $T C$ & TV & $T b$ & $T$ & $T C$ & $T V$ & $T b$ & $T$ \\
\hline \multirow[t]{6}{*}{ BCT } & Donkey & 673 & 5 & 7 & 0 & 12 & 0.74 & 1.84 & 0.00 & 2.58 & 4.82 & 10.70 & 0.00 & 11.79 \\
\hline & Cattle & 31,048 & 712 & 642 & 7 & 1881 & 7.86 & 6.43 & 0.00 & 13.69 & 24.26 & 21.15 & 0.11 & 30.54 \\
\hline & Camels & 1 & 0 & 0 & 0 & 0 & 0.00 & 0.00 & 0.00 & 0.00 & & & & \\
\hline & Goats & 801 & 2 & 6 & 0 & 8 & 0.10 & 0.40 & 0.00 & 0.50 & 0.78 & 2.82 & 0.00 & 3.28 \\
\hline & Horses & 17 & 0 & 0 & 0 & 0 & 0.00 & 0.00 & 0.00 & 0.00 & 0.00 & 0.00 & 0.00 & 0.00 \\
\hline & Sheep & 1850 & 2 & 18 & 0 & 20 & 0.05 & 0.97 & 0.00 & 1.03 & 0.84 & 4.92 & 0.00 & 5.05 \\
\hline Subtotal & & 34,390 & 721 & 673 & 7 & 1921 & 6.11 & 5.19 & 0.00 & 10.94 & 21.56 & 18.97 & 0.10 & 27.64 \\
\hline PCR & Cattle & 2806 & 512 & 508 & 8 & 965 & 9.49 & 14.78 & 0.11 & 22.84 & 19.20 & 23.11 & 0.84 & 28.81 \\
\hline \multirow[t]{6}{*}{ Elisa } & Donkey & 481 & 7 & 26 & 6 & 29 & 1.28 & 5.51 & 1.46 & 5.99 & 5.16 & 15.20 & 6.75 & 15.29 \\
\hline & Cattle & 13,781 & 2444 & 4258 & 1069 & 6316 & 24.39 & 40.00 & 11.85 & 47.21 & 32.93 & 35.20 & 24.68 & 35.70 \\
\hline & Camels & 1 & 1 & 1 & 1 & 1 & 100 & 100 & 100 & 100 & & & & \\
\hline & Goats & 457 & 5 & 25 & 16 & 43 & 0.82 & 4.84 & 2.13 & 7.48 & 3.51 & 13.95 & 6.09 & 15.76 \\
\hline & Horses & 4 & 0 & 0 & 0 & 0 & 0.00 & 0.00 & 0.00 & 0.00 & 0.00 & 0.00 & 0.00 & 0.00 \\
\hline & Sheep & 1009 & 98 & 162 & 48 & 203 & 6.01 & 9.48 & 2.27 & 12.40 & 15.22 & 23.68 & 7.56 & 25.81 \\
\hline Subtotal & & 15,733 & 2555 & 4472 & 1140 & 6592 & 18.78 & 31.17 & 9.26 & 37.03 & 30.28 & 34.94 & 21.97 & 36.55 \\
\hline \multirow[t]{6}{*}{ Total } & Donkey & 1154 & 12 & 33 & 6 & 41 & 0.96 & 3.32 & 0.59 & 3.95 & 4.96 & 12.80 & 4.33 & 13.39 \\
\hline & Cattle & 49,654 & 3747 & 5505 & 1105 & 9686 & 13.04 & 17.44 & 3.64 & 24.51 & 27.80 & 30.37 & 14.67 & 35.31 \\
\hline & Camels & 2 & 1 & 1 & 1 & 1 & 50.00 & 50.00 & 50.00 & 50.00 & 70.71 & 70.71 & 70.71 & 70.71 \\
\hline & Goats & 1258 & 7 & 31 & 16 & 51 & 0.39 & 2.18 & 0.85 & 3.29 & 2.32 & 9.33 & 3.98 & 10.82 \\
\hline & Horses & 21 & 0 & 0 & 0 & 0 & 0.00 & 0.00 & 0.00 & 0.00 & 0.00 & 0.00 & 0.00 & 0.00 \\
\hline & Sheep & 2859 & 100 & 180 & 48 & 223 & 2.32 & 4.21 & 0.86 & 5.36 & 9.83 & 15.65 & 4.79 & 17.29 \\
\hline General total & & 54,948 & 3867 & 5750 & 1176 & 10,002 & 10.47 & 14.32 & 3.02 & 20.12 & 25.24 & 28.14 & 13.23 & 33.05 \\
\hline
\end{tabular}

Tc T. congolense, Tv T. vivax; Tb: T. brucei, $T$ number of animals infected, [n] number, [\%] prevalence

Furthermore, the diagnostic technique used to test blood samples was the BCT for more than $60 \%$ of the samples. While parasitological techniques based on blood concentration may be appropriate for treatment decisions [39], they are known to have low sensitivity and to underestimate the true prevalence of the disease [35].

Despite the limitations, the atlas provides a fairly accurate assessment of the geographic distribution of three tsetse species of veterinary importance in Burkina Faso: G. palpalis gambiensis, G. tachinoides and G. morsitans submorsitans. Glossina medicorum, because of its limited distribution, has a very low impact on AAT transmission in Burkina Faso. A fifth species, G. longipalpis, had been reported in Burkina Faso, in particular in the south-west region in the zone of Batié [37]. However, the last observation was in 1961 [37], and recent data from this region are insufficient to rule out its possible persistence.

Thanks to their capacity to adapt to land cover changes and vegetation degradation, tsetse species of the riverine group (i.e. palpalis group) are confirmed to be the most widespread in Burkina Faso [37]. In particular, the geographical range of G. tachinoides extends from the east to the west of the country, and the species is now also found in some previously free areas (e.g. western part of the Orodara department) [37].

As regards savannah species, their distribution is fragmented and confined to a few protected areas. This pattern has been observed in other countries in western Africa [18], as a result of habitat degradation, land cover changes and the depletion of the wild fauna, their preferred hosts [40]. Glossina morsitans submorsitans is found along the southern border between Burkina Faso and Ghana and Benin, as well as in the pastoral zones in the western part of the country (Samorogouan and Sideradougou). Glossina medicorum was reported from one province in the south-western part of the country (Comoé), while it had also been previously reported along of the borders with Ghana, Togo and Benin [37].

Regarding animal trypanosomosis, the three major trypanosome species infective for livestock ( $T$. vivax, $T$. congolense and T. brucei) are widespread in the country. Serologically positive animals, not confirmed parasitologically, have also been reported from the north of the 
country (Djibo department) [33]. The absence of parasitological confirmations in these areas is ascribed to the combined effect of the absence of biological vectors and the trypanocidal drug treatments administered by livestock keepers before, during and after transhumance in the AAT enzootic area [33]. In this context, it is unclear whether any of the serologically positive animals identified in the northern area have been infected locally.

In Burkina Faso, T. vivax is the most widespread trypanosome species, followed by $T$. congolense. This can be ascribed to different factors, including the vectorial competence of different tsetse flies [41-44], and mechanical transmission by haematophagous flies such as Stomoxys and Tabanids [45]. Indeed, T. vivax is typically effectively transmitted by tsetse flies of the palpalis group, which are prevailing in Burkina Faso. Conversely, T. congolense and $T$. brucei are more frequently transmitted by tsetse of the morsitans group, which in Burkina Faso are now restricted to a few protected areas. Mechanical transmission also plays a role in the relative abundance of trypanosome species because, even though mechanical transmission of T. congolense is possible [45], this mode of transmission is normally much more important for $T$. vivax. Indeed, in some contexts, mechanical transmission is known to act as an amplifier of AAT transmission [46-48].

As to T. brucei, it was found mainly confined to protected areas in the west, south-west and centre-east of the country. These areas are of economic interest to the country, as they include pastoral areas, a park and a reserve.

In the development of our atlas, no data on T. evansi infections were retrieved. Trypanosoma evansi is the causative agent of 'surra', and its occurrence in Burkina Faso is mentioned in a narrative review by Desquesnes et al. [49]. However, a recent systematic literature review did not identify any reference to this effect [50]. Indeed, in Africa T. evansi is mainly reported from dromedary camels, a host species for which very limited data are available in Burkina Faso. Similar considerations apply to the absence of data on pigs and the absence of reports on T. simiae infections.

The pooled prevalence of AAT in different hosts varies depending on animal species and the detection methods used. The prevalence is higher in cattle than in the other livestock species. This can be ascribed to the predominantly extensive cattle breeding system, which relies on natural pastures. Higher AAT prevalence was reported with serological techniques, which is mainly due to the persistence of the antibodies over several months after curative treatment or the possibility of low undetectable parasitaemia in parasitological techniques [51-54].

\section{Conclusion}

The main achievement of the present study was to compile and georeference most of the available data on tsetse and AAT occurrence in Burkina Faso for a 30-year period. It also allowed us to generate updated maps of tsetse and AAT distribution at the national level. Our data show that animal trypanosomosis is widespread in Burkina Faso, even though tsetse flies are mainly confined to the west, south-west and east of the country. The disease therefore poses a constraint to the development of the livestock and agricultural sectors at the national level. The prevalence of AAT is highest in the west, which is considered the breadbasket of the country. The newly developed national atlas represents a valuable tool to support the progressive control of AAT at the national level, in particular to target and monitor surveillance and control activities. The development of the atlas also helped to develop capacities for data management of all the involved partners. It promoted synergies among national institutions for data collection and sharing, and the establishment of mechanisms for regular updating and upgrading. With a view to filling the present geographical gaps, AAT data collection could include the east, northeast and the centre where data are not available. Entomological surveys could also include the Batié area to update the status of G. longipalpis. Additional work may be carried out to include tsetse fly infections in the atlas.

\section{Abbreviations \\ AAT: African animal trypanosomosis; AfDB: African Development Bank; BCT: Buffy coat technique; PCR: Polymerase chain reaction; IBD-CETT: Insectarium de Bobo-Dioulasso-Campagne d'Eradication de la Lutte contre les Mouches tsé-tsé et de la Trypanosomose (Coordination Unit for Tsetse and Animal Trypanosomosis Control); FAO: Food and Agriculture Organization of the United Nations; IRD: Institut de recherche pour le développement; CIRAD: Centre de coopération internationale en recherche agronomique pour le développement; CIRDES: Centre International de Recherche-Développement sur l'Elevage en zone Subhumide; ELAT: Ecole de Lutte anti-tsetse; GPS: Global Positioning System; HAT: Human African trypanosomosis; IAEA: International Atomic Energy Agency; PATTEC: Pan-African Tsetse and Trypanosomosis Eradi- cation Campaign; PCP: Progressive control pathway; PCV: Packed cell volume; UTM: Universal Transverse Mercator; WGS84: World Geodetic System 1984.}

\section{Supplementary Information}

The online version contains supplementary material available at https://doi. org/10.1186/s13071-021-05131-4.

Additional file 1: Text S1. List of scientific publications that contributed to developing the national atlas of tsetse and African animal trypanosomosis in Burkina Faso.

Additional file 2: Text S2. Structure of the tsetse database Additional file 3: Text S3. Structure of the African animal trypanosomosis database 


\section{Acknowledgements}

We thank the FAO and the Government of Burkina Faso for the unlimited support given to the IBD-CETT which enabled the compilation of all the data presented in this paper. We also thank all the institutions involving in Tsetse and AAT control and research in Burkina Faso, CIRDES, IRD, CIRAD, ELAT, University of Dedougou, for their availability and their raw data sharing. Participation of integrated pest and vectors management staff of the General Direction of IBDCETT in the data collection process is gratefully acknowledged. The assistance offered by the FAO, including training of staff, scientific visits and supervision of atlas development, is greatly appreciated.

\section{Authors' contributions}

$L P, J B R, M P, I S, M O$ and GC made substantial contributions to conception and design the study, LP, MP, SPH, MO, JBR, GG, SP, AS and GC participate to the data collection; LP, JBR, MP and GC analysed the data; and LP, MP, JBR, GG, SP, SPH, IS and GC participated in the writing the manuscript. All authors read and approved the final manuscript.

\section{Funding}

The national atlas of tsetse and AAT in Burkina Faso is an initiative of the Government of Burkina Faso, through its General direction IBD-CETT. FAO assistance to this study was provided in the framework of the Programme against African Trypanosomosis (PAAT), and supported by the Government of Italy (Project'Improving food security in sub-Saharan Africa by supporting the progressive reduction of tsetse-transmitted trypanosomosis in the framework of the NEPAD', codes GTFS/RAF/474/ITA and GCP/RAF/502/ITA). Financial support was also provided by the IAEA.

\section{Availability of data and materials}

Relevant data are within the paper and its additional files. The bulk of the data of the atlas of tsetse and AAT in Burkina Faso is the property of the Government of Burkina Faso, Ministère des Ressources Animales et Halieutiques, Insectarium de Bobo-Dioulasso-Campagne d'Eradication de la Lutte contre les Mouches tsé-tsé et de la Trypanosomose, (IBD-CETT). Data can be requested from: Director General, PO Box: 1087, Bobo-Dioulasso 01, Burkina Faso, Phone: +226 20 970955/971521, website: www.pattec.bf.

\section{Declarations}

\section{Ethics approval and consent to participate}

Not applicable.

\section{Consent for publication}

Not applicable.

\section{Competing interests}

The authors declare that they have no competing interests.

\section{Author details}

${ }^{1}$ Insectarium de Bobo-Dioulasso-Campagne Panafricaine d'Eradication de la Tsé-tsé et de la Trypanosomose, Bobo-Dioulasso, Burkina Faso. ${ }^{2}$ Ecole de Lutte Anti-Tsétsé, Bobo-Dioulasso, Burkina Faso. ${ }^{3}$ Centre International de Recherche-Développement sur l'Elevage en zone subhumide, Bobo-Dioulasso, Burkina Faso. ${ }^{4}$ CIRAD, UMR INTERTRYP, Montpellier, France. ${ }^{5}$ INTERTRYP, Univ Montpellier, CIRAD, IRD, Montpellier, France. ${ }^{6}$ Université de Dédougou (UDDG), BP 176, Dédougou, Burkina Faso. ${ }^{7}$ Agence de Formation, de Recherche et d'Expertise en Santé pour l'Afrique (AFRICSanté), 01 BP 298, Bobo-Dioulasso 01, Burkina Faso. ${ }^{8}$ Food and Agriculture Organization of the United Nations, Emergency Centre for Transboundary Animal Diseases (ECTAD), Conakry, Guinea. ${ }^{9}$ Joint FAO/IAEA Centre of Nuclear Techniques in Food and Agriculture, Vienna, Austria. ${ }^{10} \mathrm{CIRAD}$, UMR, ASTRE, Montpellier, France. ${ }^{11}$ Food and Agriculture Organization of the United Nations, Animal Production and Health Division, Rome, Italy.

Received: 17 August 2021 Accepted: 13 December 2021 Published online: 04 March 2022

\section{References}

1. Büscher P, Cecchi G, Jamonneau V, Priotto G. Human African trypanosomiasis. The Lancet. 2017;390:2397-409.

2. Taylor K, Authié EML. Pathogenesis of animal trypanosomiasis. In: Maudlin I, Holmes PH, Miles MA, editors. The trypanosomiases. CABI Publishing: Wallingford; 2004. p. 331-53.

3. Alsan M. The effect of the tsetse fly on African development development. Am Econ Rev. 2014;1:382-410.

4. Cattand P, editor. Linking sustainable human and animal African Trypanosomosis control with rural development strategies. Rome: Food and Agriculture Organization of the United Nations; 2010.

5. Kristjanson PM, Swallow BM, Rowlands GJ, Kruska RL, de Leeuw PN. Measuring the costs of African animal trypanosomosis, the potential benefits of control and returns to research. Agric Syst. 1999. https://doi.org/10. 1016/S0308-521X(98)00086-9.

6. Shaw APM, Cecchi G, Wint GRW, Mattioli RC, Robinson TP. Mapping the economic benefits to livestock keepers from intervening against bovine trypanosomosis in Eastern Africa. Prev Vet Med. 2014;113:197-210.

7. Simarro PP, Cecchi G, Franco JR, Paone M, Diarra A, Ruiz-Postigo JA, et al. Estimating and mapping the population at risk of sleeping sickness. PLoS Negl Trop Dis. 2012;6:e1859.

8. Franco JR, Cecchi G, Priotto G, Paone M, Diarra A, Grout L, et al. Monitoring the elimination of human African trypanosomiasis at continental and country level: Update to 2018. Matovu E, editor. PLoS Negl Trop Dis. 2020;14:e0008261.

9. Sow A, Sidibé I, Bengaly Z, Bouyer J, Bauer B, Van den Bossche P. Fifty years of research and fight against tsetse flies and animal trypanosomosis in Burkina Faso. An overview. Bull Anim Health Prod Afr. 2010. https://doi. org/10.4314/bahpa.v58i2.62044.

10. MRA ADS. Les Statistiques du Secteur de L'Elevage au Burkina Faso. 2006;64.

11. Kamuanga M, Swallow BM, Sigué H, Bauer B. Evaluating contingent and actual contributions to a local public good: Tsetse control in the Yale agro-pastoral zone. Burkina Faso Ecol Econ. 2001;39:115-30.

12. Sow A, Ganaba R, Percoma L, Sidibé I, Bengaly Z, Adam Y, et al. Baseline survey of animal trypanosomosis in the region of the Boucle du Mouhoun. Burkina Faso Res Vet Sci. 2013;94(3):573-8.

13. Kabayo J. Aiming to eliminate tsetse from Africa. Trends Parasitol. 2002;18:473-5.

14. Percoma L, Adama S, Pagabeleguem S, Dicko AH, Serdebéogo O, Ouédraogo M, et al. Impact of an integrated control campaign on tsetse populations in Burkina Faso. Parasit Vectors. 2018. https://doi.org/10. 1186/s13071-017-2609-3.

15. Diall O, Cecchi G, Wanda G, Argilés-Herrero R, Vreysen MJB, Cattoli G, et al. Developing a progressive control pathway for African animal trypanosomosis. Trends Parasitol. 2017:33:499-509.

16. Cecchi G, Paone M, Feldmann U, Vreysen MJ, Diall O, Mattioli RC. Assembling a geospatial database of tsetse-transmitted animal trypanosomosis for Africa. Parasit Vectors. 2014;7(1):1-10. https://doi.org/10.1186/ 1756-3305-7-39.

17. Cecchi G, Paone M, Argilés Herrero R, Vreysen MJB, Mattioli RC. Developing a continental atlas of the distribution and trypanosomal infection of tsetse flies (Glossina species). Parasit Vectors. 2015;8(1):1-10. https://doi. org/10.1186/s13071-015-0898-y.

18. de Gier J, Cecchi G, Paone M, Dede P, Zhao W. The continental atlas of tsetse and African animal trypanosomosis in Nigeria. Acta Trop. 2020:204:105328.

19. Ahmed SK, Rahman AH, Hassan MA, Salih SEM, Paone M, Cecchi G. An atlas of tsetse and bovine trypanosomosis in Sudan. Parasit Vectors. 2016;9:1-8.

20. Diarra B, Diarra M, Diall O, Bass B, Sanogo Y, Coulibaly E, et al. A national atlas of tsetse and African animal trypanosomosis in Mali. Parasit Vectors. 2019;12:1-10

21. Ngari NN, Gamba DO, Olet PA, Zhao W, Paone M, Cecchi G. Developing a national atlas to support the progressive control of tsetse-transmitted animal trypanosomosis in Kenya. Parasit Vectors. 2020;13:1-12. 
22. Shereni W, Neves L, Argilés R, Nyakupinda L, Cecchi G. An atlas of tsetse and animal African trypanosomiasis in Zimbabwe. Parasit Vectors. 2021;14:1-10

23. Challier A, Laveissiere C. Un nouveau piège pour la capture des glossines (Glossina: Diptera, Mstscidae) : description et essais sur le terrain. 1973;XI:251-62.

24. Percoma L, Koudougou Z, Serdebeogo O, Tamboura I, Ouedraogo M, Bouyer J, et al. Enquêtes entomologiques préparatoires à une lutte à grande échelle contre les glossines, assistées par un système d'information géographique : cas de la Pattec au Burkina Faso. Rev D'élevage Médecine Vét Pays Trop. 2016;68:157.

25. Laveissière C. Grébaut P [The trapping of tsetse flies (Diptera: Glossinidae). Improvement of a model: the Vavoua trap]. Trop Med Parasitol Off Organ Dtsch Tropenmedizinische Ges Dtsch Ges Tech Zusammenarbeit GTZ. 1990;41:185-92.

26. Amsler S, Filledier J, Millogo R. Efficacité comparée de différents pièges pour la capture de Glossina tachinoides (Diptera : Glossinidae) au Burkina Faso. Rev Elev Med Vet Pays Trop. 1994;47(2):207-14.

27. Rayaisse J-B, Kröber T, McMullin A, Solano P, Mihok S, Guerin PM. Standardizing visual control devices for tsetse flies: West African species Glossina tachinoides, G. palpalis gambiensis and G. morsitans submorsitans. Masiga DK, editor. PLoS Negl Trop Dis. 2012;6:e1491.

28. Rayaisse JB, Tirados I, Kaba D, Dewhirst SY, Logan JG, Diarrassouba A, et al. Prospects for the Development of Odour Baits to Control the Tsetse Flies Glossina tachinoides and G. palpalis s.I. Ndung'u JM, editor. PLoS Negl Trop Dis. 2010;4:e632.

29. McDermott J, Woitag T, Sidibé I, Bauer B, Diarra B, Ouédraogo D, et al. Field studies of drug-resistant cattle trypanosomes in Kénédougou Province. Burkina Faso Acta Trop. 2003;86:93-103.

30. Sow A, Sidibé I, Bengaly Z, Marcotty T, Séré M, Diallo A, et al. Field detection of resistance to isometamidium chloride and diminazene aceturate in Trypanosoma vivax from the region of the Boucle du Mouhoun in Burkina Faso. Vet Parasitol. 2012;187:105-11.

31. Koné N, N'Goran EK, Sidibe I, Kombassere AW, Bouyer J. Spatio-temporal distribution of tsetse and other biting flies in the Mouhoun River basin. Burkina Faso Med Vet Entomol. 2011;25:156-68.

32. Courtin F, Rayaissé J-B, Tamboura I, Serdébéogo O, Koudougou Z, Solano P, et al. Updating the northern tsetse limit in Burkina Faso (1949-2009): impact of global change. Int J Environ Res Public Health. 2010;7:1708-19.

33. Pagabeleguem $S$, Sangaré $M$, Bengaly $Z$, Akoudjin M, Belem AMG, Bouyer J. Climate, Cattle Rearing Systems and African Animal Trypanosomosis Risk in Burkina Faso. Igarashi I, editor. PLoS ONE. 2012;7: e49762.

34. Murray M, Murray PK, Mcintyre WI. Improved parasitological technique for diagnosis of African trypanosomiasis. Trans R Soc Trop Med Hyg. 1977;71(4):325-6.

35. Desquesnes M, Michel JF, de La Rocque S, Solano P, Millogo L, Bengaly Z, et al. Enquête parasitologique et sérologique (ELISA-indirect) sur les trypanosomoses des bovins dans la zone de Sidéradougou, Burkina Faso. Burkina Faso. 1999. https://doi.org/10.19182/remvt.9667.

36. Silbermayr K, Li F, Soudré A, Müller S, Sölkner J. A novel qPCR assay for the detection of African animal trypanosomosis in trypanotolerant and trypanosusceptible cattle breeds. Solano P, editor. PLoS Negl Trop Dis. 2013;7:e2345.

37. Challier A, Laveissière C. La répartition des glossines en Haute-Volta, carte à 1/2 000 000. Paris: Office de la recherche scientifique et technique outre-mer; 1977.

38. Kamuanga M, Kaboré I. La lutte contre les glossines dans la zone agropastorale de Yalé (Burkina Faso): résultats d'enquêtes socio-économiques. Tropicultura. 2005;23:146-53.

39. Moti Y, Fikru R, Büscher P, Van Den Abbeele J, Duchateau L, Delespaux V. Detection of African animal trypanosomes: the haematocrit centrifugation technique compared to PCR with samples stored on filter paper or in DNA protecting buffer. Vet Parasitol. 2014;203:253-8.

40. Rayaissé JB, Courtin F, Akoundjin M, César J, Solano P. Influence de I'anthropisation sur la végétation locale et l'abondance des tsé-tsé au sud du Burkina Faso. Parasite. 2009:16:21-8.

41. Milby MM, Reisen WK. Estimation of vectorial capacity: vector survivorship. Bull Soc Vector Ecol. 1989;14:47-54.

42. Reifenberg J-M. Etude des relations parasites-hôtes dans l'épidémiologie moléculaire des trypanosomoses bovines au Burkina Faso. [Sciences et Techniques du Languedoc]: Montpellier II; 1996.
43. Reifenberg J-M, Solano P, Bauer B, Kaboré I, Cuny G, Duvallet G, et al. Apport de la technique PCR pour une meilleure compréhension de l'épizootiologie des trypanosomoses bovines : exemple de la zone d'aménagement pastoral de Yalé au Burkina Faso. Rev D'élevage Médecine Vét Pays Trop. 1997;50:14-22.

44. Solano P, Guégan JF, Reifenberg JM, Thomas F. Trying to predict and explain the presence of African trypanosomes in tsetse flies. J Parasitol. 2001;87:1058-63.

45. Desquesnes M, Dia ML, Acapovi G. Les vecteurs mécaniques des trypanosomoses animales. Bobo-Dioulasso: Cirdes; 2005.

46. Buxton PA. The natural history of tsetse flies; an account of the biology of the genus Glossina (Diptera). London: Lewis; 1955.

47. Mulligan HW. The African trypanosomiases. New hardcover. Tucson, AZ: Wiley-Interscience; 1970.

48. Reifenberg J-M. Etude des relations parasites-hôtes dans l'épidémiologie moléculaire des trypanosomoses bovines au Burkina Faso. Thèse de Doctorat, Université de Montpellier II, France; 1996.

49. Desquesnes M, Holzmuller P, Lai DH, Dargantes A, Lun ZR, Jittaplapong S. Trypanosoma evansi and Surra: a review and perspectives on origin, history, distribution, taxonomy, morphology, hosts, and pathogenic effects. Biomed Res Int. 2013;2013:194176. https://doi.org/10.1155/2013/194176.

50. Aregawi WG, Agga GE, Abdi RD, Büscher P. Systematic review and meta-analysis on the global distribution, host range, and prevalence of Trypanosoma evansi. Parasit Vectors. 2019;12(1):1-25.

51. Dagnachew S, Bezie M. Review on Trypanosoma vivax. African J Basic Appl Sci. 2015;7:41-64.

52. Delafosse A, Thébaud E, Desquesnes M, Michaux Y. Epidemiology of Trypanosoma vivax infection in cattle in the tse-tse free area of Lake Chad. Prev Vet Med. 2006;74:108-19.

53. Gardiner PR. Recent studies of the biology of Trypanosoma vivax. Adv Parasitol. 1989:28:229-317.

54. Fetene E, Leta S, Regassa F, Büscher P. Global distribution, host range and prevalence of Trypanosoma vivax: a systematic review and meta-analysis. Parasit Vectors. 2021;14:80.

\section{Publisher's Note}

Springer Nature remains neutral with regard to jurisdictional claims in published maps and institutional affiliations.

Ready to submit your research? Choose BMC and benefit from

- fast, convenient online submission

- thorough peer review by experienced researchers in your field

- rapid publication on acceptance

- support for research data, including large and complex data types

- gold Open Access which fosters wider collaboration and increased citations

- maximum visibility for your research: over $100 \mathrm{M}$ website views per year

At BMC, research is always in progress.

Learn more biomedcentral.com/submissions 